\title{
Socialkonstruktivisme, sprog og identitet
}

\section{Identitetsforhandlinger på Eva Dien Brine Markvoorts sygdoms- blog 65 Red Roses}

\author{
Carsten Stage \\ Aarhus Universitet
}

\begin{abstract}
Socialkonstruktivismen har været genstand for heftig kritik for at underst $\varnothing t t e$ en form for begrebsrelativisme, der påstår, at virkeligheden skabes af vores begreber om den. Et delmål med artiklen er at gøre op med denne karikatur af konstruktivismen som en homogen teoretisk position, der reducerer alt til sprog og italesættelse eller indebærer en tro på, at alle identiteter blot er effekter af begreber. Dette gøres ved at præsentere og diskutere teorier af bl.a. Michel Foucault, Ernesto Laclau og Chantal Mouffe, Judith Butler, Stuart Hall, Karl Popper og Richard Jenkins med det formål at kunne skelne mellem forskellige former for, eller grader af, konstruktivisme. De forskellige konstruktivismeformers udsigelseskraft diskuteres dernæst gennem en analyse af et medieobjekt - Eva Dien Brine Markvoorts sygdomsblog 65 Red Roses.
\end{abstract}

"(...) we view constructionism as an empirical programme of investigation that has the potential to incorporate and adequately theorize both the discursive and extra-discursive aspects of our being while remaining grounded in a necessarily 'partial' and always revisable ontology" David Nightingale \& John Cromby, 2002:710-711.

\section{Indledning}

Denne artikels empiriske udgangspunkt er Eva Dien Brine Markvoorts (fremover EM) (1984-2010) sygdomsblog 65 Red Roses ${ }^{1}$, der primært fokuserer på EMs liv med den dødelige genetiske lungesygdom cystisk fibrose, men også på hendes hverdagsaktivistiske kamp for at skabe øget opmærksomhed på sygdommen og nødvendigheden af, at flere melder sig som organdonorer. Bloggen er en multimodal kommunikationsplatform (Kress and Leeuwen 2001) kendetegnet af både skriftlige, visuelle og audiovisuelle udtryk. Der er i skrivende stund 552 indlæg på blog- 


\section{Carsten Stage}

gen, hvoraf langt de fleste er skrevet af EM, mens et fătal er uploaded af hendes pårørende - især i forbindelse med operationer eller indlæggelser, hvor EM ikke selv har kunnet blogge.

Bloggens første indlæg er skrevet 15. juli 2006, og bloggen kan derefter inddeles i tre hovedfaser, som dækker de sidste fire år af EMs liv. Den første fase fra juli 2006 til slutningen af oktober 2007 følger EMs tilværelse med cystisk fibrose og den tiltagende forværring, som fører til, at hun får lavet en dobbelt lungetransplantation. Den anden fase fra ultimo oktober 2007 til slutningen af august 2009 omhandler EMs opblomstring efter operationen, som gør det muligt for hende at leve et aktivt liv uden voldsomme men af sygdommen, samt tiden hvor en dokumentar om hendes indtil da vellykkede sygdoms- og operationsforløb er under offentliggørelse. Den sidste fase, der indvarsles med en entry d. 30. august 2009, følger perioden, hvor EMs krop langsomt begynder at afstøde de transplanterede lunger, hvilket fører til, at hun mister livet d. 27. marts 2010. Derefter bruges bloggen til at livestreame en mindeceremoni for EM og dernæst til, at hendes pårørende følger op på de mange kampagner og initiativer, som EM havde involveret sig i. Bloggen står dermed i dag som en unikt spor af et sygdomsforløb, men fungerer ligeledes som et minde om og redskab for den mikropolitiske kamp, som EM førte.

Bloggen kan analyseres på flere forskellige måder, fx med fokus på internettets eller bloggens betydning for terminalt syge og offentlighedens ændrede relation til døden/døende, eller på affektens betydning for bloggens kommunikation og dens voksende skare af læsere. Disse emner har jeg gjort til genstand for analyser i andre sammenhænge (Stage 2013, 2014), men inden for rammen af dette særnummer vil mit fokus være 1) relationen mellem sprogbrug, identitetsdannelse og sygdom i forhold til bloggen og 2) en diskussion af et konstruktivistisk identitetsbegrebs relevans for analysen af EMs sygdomsblog. I artiklen vil jeg således undersøge følgende to analysespørgsmål: Hvilket identitetsarbejde udfoldes gennem bloggens kommunikation, dvs. hvordan italesætter EM sin identitet, og hvordan tager omverdenen mod disse italesættelser? Er identiteten som terminalt syg også sprogligt konstrueret (og i så fald hvordan), eller møder den sociale konstruktionstænkning netop sin grænse i sådanne tilfælde?

Før jeg går videre, er der en etisk problemstilling angående brugen af meget personlig empirisk materiale, som må adresseres. Under normale omstændigheder ville man spørge bloggeren om lov til at ind- 


\section{Socialkonstruktivisme, sprog og identitet}

drage hans/hendes kommunikation til forskningsformål, men dette er selvsagt ikke muligt i dette tilfælde. Denne umulighed ændrer ikke på det grundlæggende dilemma: Er det tilladeligt at lave analyser af identitetskonstruktioner i webkommunikation i et materiale, der er så tæt knyttet til individers lidelser og død som 65 Red Roses er det? Dette spørgsmål kan ikke besvares generelt, men i forhold til EMs blog vil jeg argumentere for, at det er forsvarligt af en række årsager (Heilferty 2011). Bloggen har hele tiden været offentlig tilgængelig og EM kommunikerer konstant med en bevidsthed om, at det skrevne kan nå en bredere offentlighed. Dette er allerede tydeligt for EM undervejs i forløbet, da hendes liv pludselig bliver genstand for stor offentlig interesse på grund af dokumentarfilmen 65_Redroses (2009) af Phillip Lyall og Nimisha Mukerji. Interessen får hende dog ikke til at kommunikere mindre (privat) på bloggen, hvilket viser, at hun bevidst blogger til en bredere offentlighed om sin sygdom. Dette understreges igen af, at hun fra maj 2009 (dvs. lang tid før de meget private indlæg om hendes forværrede tilstand) selv skelner mellem private indlæg, som når en mindre gruppe af 'godkendte' læsere, og en alment tilgængelig blog, som alle kan læse, og som denne artikel forholder sig til. ${ }^{2}$

Det er ganske simpelt en af EMs grunde til at lave bloggen, at hun $\varnothing$ nsker at sprede viden om sin person og sygdom, og hun optræder således i et hav af skrevne og audiovisuelle medier for at nå dette mål. ${ }^{3}$ Bloggen er dermed at betragte som en art sproglig aktivismepraksis, der handler om at få omverden i tale i forhold til en sygdom, som meget få kender til. EM er desuden selv meget kommunikerende i forhold til sin dødsproces, som hun bl.a. fortæller om i en intim afskedsvideo, ligesom en mindeceremoni som nævnt streames live af hendes familie på bloggen. Sygdommen og lidelserne behandles altså ingenlunde som en privatsag af EM og hendes pårørende, men snarere som størrelser, der burde få mere politisk og social opmærksomhed. At analysere bloggen i en akademisk artikel er i lyset af disse forhold for mig at se derfor ikke en forstyrrende analytisk intervention i et privat rum. Nærværende artikel er snarere i tråd med EMs ønske om, at hendes historie skal nå et bredere publikum end en 'afprivatisering' af noget ellers privat.

Artiklen er struktureret på en made, så der først redegøres for forskellige forståelser af konstruktivismebegrebet og dets relevans for identitetsdannelsesprocesser, hvorefter bloggen analyseres med særligt fokus på de problemstillinger, jeg berører i teoriafsnittet. Min metode er inspireret af en diskursanalytisk tilgang (Foucault 2005, Laclau and Mouffe 2001, Jørgensen and Phillips 2006), idet jeg har gennemgået et 


\section{Carsten Stage}

stort empirisk materiale (dvs. bloggens mere end 500 indlæg samt andre medietekster om EM) med fokus på de bredere tendenser/diskurser, hvad angår italesættelsen af EMs identitet som terminalt syg, der kan findes i empirien. Disse bredere tendenser analyseres på den ene side gennem læsninger af repræsentative eksempler fra bloggen og på den anden side gennem analyser af teksternes evne til at påvirke både EMs sociale identitet og diskurser i deres distributionskontekst. Afsluttende vil jeg diskutere konstruktivismens relevans for en præcis forståelse af casen.

\section{Konstruktivisme og identifikation}

Min teoretiske horisont vil primært være inspireret af såkaldt 'konstruktivistiske' identitetsteorier. ${ }^{4}$ Konstruktivismen har længe været genstand for heftig kritik for at understøtte en form for begrebsrelativisme, der påstår, at virkeligheden skabes af vores begreber om den. Et delmål med artiklen er at gøre op med denne karikatur af konstruktivismen som en teoretisk position, der reducerer alt til sprog og italescettelse eller indebærer en tro på, at alle identiteter blot er effekter af begreber. Men i første omgang: Hvad er 'konstruktivisme' overhovedet?

\subsection{Konstruktivismer}

Vivien Burrs standardværk Social Constructionism præsenterer socialkonstruktivisme som "any approach which has as its foundation one or more of the following key assumptions" (Burr 2003: 2): 1) Ideen om neutral eller ikke-fortolkende viden må problematiseres, 2) forståelse af og tale om verden afspejler en specifik historisk og kulturel kontekst, 3) viden skabes igennem sociale og kollektive processer, 4) den sociale konstruktion af viden har sociale konsekvenser, fordi vidensproduktionen er handlingsregulerende. Ifølge Burr er alle konstruktivister ikke nødvendigvis lige enige om eller fokuserede på disse fire meget generelle antagelser.

Filosofiprofessor Finn Collin skelner mellem forskellige grader af konstruktivisme. Den radikale konstruktivisme hævder ifølge Collin, "at et eller andet fænomen, som vi normalt opfatter som uafhængigt eksisterende, i virkelighed er frembragt eller "konstrueret" igennem menneskers tænkning, sprog og sociale praksisser" (Collin 2003:11). Et eksempel kunne være ideen om, at naturvidenskaben ikke afdækker objektive processer, men i virkeligheden er med til at skabe dem ved at møde verden gennem særlige begreber og unders $\emptyset$ gelsespraksisser. Den mere moderate konstruktivisme mener, "at et eller andet 


\section{Socialkonstruktivisme, sprog og identitet}

fænomen, som normalt opfattes som noget, der "ligger i tingenes orden" og dermed er naturligt, universelt, tidlфst, givet, selvfфlgeligt eller ligefrem $n \phi d v e n d i g t$, ved nærmere undersøgelse viser sig at være lokalt og historisk variabelt" (Collin 2003:11). Den radikale konstruktivist ser altså virkeligheden som et produkt af subjekters begreber, mens den moderate konstruktivisme snarere handler om at kontekstualisere sociale fænomener, som fejlagtig betragtes som ahistoriske og naturgivne.

Den moderne konstruktivisme kan ifølge Collin overordnet splittes i to hovedretninger: en videnssociologisk tradition med fokus på naturvidenskabens erkendelsesprocesser (fx Karin Knorr Cetina, Harry Collins, Steve Fuller og Bruno Latour) og en human- og samfundsvidenskabelig tradition med fokus på sociale og politiske problemstillinger (fx Michel Foucault, Niklas Luhmann og Laclau og Mouffe). Med Collin kan den moderne konstruktivisme som tradition i og for sig koges ned til fire grundargumenter, der sammensætter parametrene erkendelse vs. ontologi og fysisk virkelighed vs. social virkelighed på forskellige måder. Som sådan kan der etableres fire konstruktivistiske grundudsagn, som den enkelte teori kan bekræfte mere eller mindre: 1) den fysiske virkelighed er en konstruktion af vores videnskabelige viden om den, 2) vores videnskabelige viden om den fysiske virkelighed er en konstruktion, 3) den sociale virkelighed er en konstruktion af vores videnskabelige, dagligdags eller abstrakte viden om den, og 4) vores viden om den sociale virkelighed er en konstruktion (Collin 2003:24).

Pointen med at opregne disse forskellige former for konstruktivisme er for mit vedkommende for det første at slå fast, at man ikke kan tale om og kritisere konstruktivismen som en enhed, og for det andet at argumentere for, at en generel kritik af konstruktivismen som radikal begrebsrelativisme er forfejlet: der findes utallige og meget lidt kontroversielle måder at være konstruktivist på. Sidst, men ikke mindst, bruger jeg senere de fire udsagn til at diskutere, hvilken form for konstruktivisme, der er mest anvendelig i forhold til en analyse af EMs sygdomsblog. Det er her vigtigt at slå fast, at jeg ikke dermed hævder, at casen/bloggen kan bruges til en gang for alle at verificere eller teste det ene konstruktivistiske grundudsagn på bekostning af de andre, men snarere til at bidrage til den kritisk-akademiske diskussion om konstruktivismens former og anvendelighed. Videnskabsfilosoffen Karl R. Popper skelner i den forbindelse mellem to former for videnskabelig kritik - en fejlagtig og en korrekt: 


\section{Carsten Stage}

The mistaken method starts from the question: How can we establish or justify our thesis or our theory? It thereby leads to either dogmatism, or to an infinite regress, or to the relativistic doctrine of rationally incommensurable frameworks. By contrast, the correct method of critical discussion starts from the question: What are the consequences of our thesis or our theory? Are they all acceptable to us? It thus consists in comparing the consequences of different theories (or, if you like, of different frameworks) and tries to find out which of the competing theories or frameworks has consequences that seem preferable to us (Popper 1994:60)

I forlængelse af Popper forsøger min artikel netop at sammenligne "the consequences of different theories" (eller konstruktivistiske positioner) ved at diskutere de enkelte teoriers evne til at producere sandsynlig viden om en case. Poppers pointe er, at en sådan proces af kritisk diskussion på sigt vil føre til mere nuanceret vidensproduktion - selvom den aldrig kan verificeres endegyldigt - fordi de enkelte teorier hele tiden udsættes for kritiske tests, som fører til, at de til- eller fravælges som forklaringsmodeller i forhold til diverse problemstillinger (Popper, 1994:3).

For de fleste vil det første grundudsagn i Collins typologi uden tvivl være det mest kontroversielle, fordi det i sin yderste konsekvens anfægter selve den fysiske virkeligheds (fx naturlovenes) uafhængighed af menneskeskabt viden, og spørgsmålet er, hvor mange anerkendte og anvendte teorier der for alvor opretholder dette standpunkt. Findes der fx eksempler på akademisk udbredte teorier, der vil forfægte, at hvis vi blot blev enige om et omvendt tyngdelovsprincip, så ville genstande holde op med at falde mod jorden? ${ }^{5}$ Andet grundudsagn vil ligeledes møde relativ modstand, fordi det i og for sig beskylder naturvidenskaben for at konstruere sine egne observationer. Michel Foucaults Naissance de la Clinique (1963), der historiserer konstruktionen af en særligt medicinsk diskurs, som understøtter "the great myth of a pure Gaze", er et eksempel på denne anden position (Foucault 1963:141). Tredje udsagn er mindre kontroversielt, idet det argumenterer for, at samfund opbygger socialitetsformer (fx sociale institutioner eller grupperinger), der afspejler den viden, samfundet ligger inde med, uden dermed at forkaste, at der kan eksistere en fysisk virkelighed, som ikke determineres direkte af denne vidensproduktion. Fjerde udsagn er nærmest ukontroversielt, idet det egentlig alene plæderer for, at en given viden om det sociale liv (fx hvad nationalisme er) udvikles over tid, og spørgsmålet 


\section{Socialkonstruktivisme, sprog og identitet}

er om dette standpunkt overhovedet genkendes som konstruktivisme, fordi det er en fuldstændig banal common sense-antagelse inden for human- og samfundsvidenskaberne.

\subsection{Det fysiske og det sociale}

Hvad angår de primære teoretiske inspirationskilder, som jeg vil trække på i det følgende - fx Ernesto Laclau \& Chantal Mouffe samt Judith Butler - knytter deres tænkning sig umiddelbart til det tredje udsagn. Deres forhold til udsagn to er dog generelt en smule uafklaret, fordi det sjældent er videnskabelig vidensproduktion, men snarere menneskers politiske indretning af socialiteten, der er i fokus. Forvirringen opstår primært, fordi ingen af dem anerkender skellet mellem det sociale og det fysiske, men samtidig synes de også at arbejde med ideen om, at der også findes en 'førsocial' (men utilgængelig) eksistensform, hvilket gør det muligt for dem at fastholde, at de ikke er 'naive' konstruktivister, der tror på, at begreber bare sådan konstituerer virkeligheden.

Ernesto Laclau \& Chantal Mouffe har meget eksplicit udfoldet den specifikke form for konstruktivisme, som de abonnerer på. Dette gør de bl.a. i teksten "Post-Marxism without Apologies", hvor de skelner mellem objekters (fysiske) 'eksistens' og deres (sociale) 'væren'. Her hedder det således, at "outside of any discursive context objects $d o$ not have being; they have only existence" (Laclau and Mouffe 1987:85). Laclau \& Mouffe indsætter i og for sig et kantiansk skel mellem 'tingen i sig selv' og 'tingen for mig' - dog med den væsentlige forskel, at de perspektiver, som subjektet møder tingene med, ifølge Laclau og Mouffe ikke er ahistoriske og universelle som hos Kant, men historiske og foranderlige. Andetsteds forklares dette skel mellem eksistens og væren mere udførligt:

To call something a natural object is a way of conceiving it that depends upon a classificatory system. Again, this does not put into question the fact that this entity which we call stone exists, in the sense of being present here and now, independently of my will; nevertheless the fact of its being a stone depends on a way of classifying objects that is historical and contingent. If there were no human beings on earth, those objects that we call stones would be there nonetheless; but they would not be 'stones', because there would be neither mineralogy nor a language capable of classifying them and distinguishing them from other objects (Laclau and Mouffe 1987:84) 


\section{Carsten Stage}

Den sociale virkelighed ( $\mathrm{f} x$ dannelsen af politiske identiteter og bevægelser) er altså en effekt af sociale konstruktioner, men en basal fysisk virkelighed (fx stenen) holdes fri af det socialt konstruerede i den forstand, at dens blotte eksistens ikke er konstitueret af menneskeskabte betydningssystemer. Laclau \& Mouffe benægter altså ikke eksistensen af en fysisk virkelighed, men fastholder, at menneskets adgang til og perception af disse objekter altid indebærer et fortolkningsarbejde, der trækker på etablerede og foranderlige antagelser og diskurser. Det tydeligg øres dog ikke, om visse fortolkninger kan være mere gyldige eller præcise i forhold til eksistensniveauet end andre - hvilket er et eksempel på det psykologiforskerne Nightinggale og Cromby kalder for "the ontological muteness of constructionism" (Nightingale and Cromby 2002:710). Er det fx mere korrekt at fortolke et regnvejr som en meteorologisk proces end som et udslag af guddommelig vrede? Grunden til, at svaret på dette spørgsmål forbliver uklart, er primært, at det altid er fortolkningernes sociale og samfundsmæssige konsekvenser (som artikulationer, der forsøger at sætte særlige virkelighedsforståelser igennem), der er Laclau \& Mouffes hovedinteresse. Målet for deres analyse er aldrig at dømme en artikulation som 'falsk', men snarere at forstå dens sociale/politiske effekter, hvilket betyder at gyldighedsproblemet forbliver relativt utematiseret i de konkrete analyser. Laclau og Mouffe pointerer dog dermed indirekte, at sproglige ytringer ikke altid kan og skal behandles analytisk i forhold til deres evne til at referere sandt eller falsk til virkelige fænomener, men også i henhold til deres evne til (eller fors $\emptyset \mathrm{g}$ på) at forme individers og gruppers virkelighedsforståelser og handlinger. Artikulationer er dermed politiske og ikke bare utvetydigt sande eller usande, hvis man følger Laclau \& Mouffe (Laclau and Mouffe 2001).

Laclau og Mouffes relevans for denne artikel skyldes deres fokus på, at menneskers sociale liv og relationer etableres og genforhandles gennem handlinger og sprogbrug (fx via en sygdomsblog). Jeg vil følgelig trække på en række overordnede erkendelser inspireret af Laclau og Mouffe: 1) reproduktionen af etablerede diskurser ${ }^{6}$ er med til at skabe særlige fortolkninger af virkeligheden, 2) diskurserne er ofte også med til at forandre virkeligheden ved at motivere/sandsynliggøre særlige former for handlinger med konkrete effekter, 3) der findes fænomener i verden, hvis blotte eksistens ikke konstitueres af diskurser, 4) etablerede diskurser er uundgåelige for enhver form for fortolkning af fænomenernes væren. En anden indirekte inspiration fra Laclau og Mouffe er pointeringen af, at en god socialanalyse sjældent er inter- 


\section{Socialkonstruktivisme, sprog og identitet}

esseret $\mathrm{i}$ at demaskere en italesættelse som falsk, men snarere $\mathrm{i}$ at forstå og undersøge den socialitet, som italesættelsen er med til at (re)producere. Dette gælder også for denne artikel: EMs kommunikation er ikke interessant inden for et sandt/falsk-perspektiv, men som et forsøg på både at forhandle EMs egen identitet og relationen mellem hende selv, hendes sygdom og det omgivende samfund.

Når dette er sagt, vil jeg dog fastholde, at den manglende evne til at forholde sig til gyldigheden af diverse artikulationer i forhold til en beskrivelse af eksistensniveauet, er en af hovedproblemerne i Laclau \& Mouffes konstruktivisme. Førnævnte Karl Popper, og den kritiske rationalisme, han repræsenterer, har netop tilbudt et nuanceret fors $\varnothing \mathrm{g}$ på både at fastholde 1) at der ikke findes en umedieret sansning af verden som tillader os at producere sandhed om virkeligheden fri af fordomme og eksisterende diskurser, men 2) at dette forhold kan kombineres med ideen om, at der hele tiden udvikles bedre og mere præcise teorier om selvsamme virkelighed. At vi ikke har 'ren' adgang til det virkelige indebærer altså ikke, at den ene teori om virkeligheden kan være lige så god som den anden: "Thus our view of the world is at any moment necessarily theory-impregnated. But this does not prevent us from progressing to better theories", som Popper skriver det i The Myth of the Framework (Popper 1994:53).

I sin betoning af, at sansningen beror på og filtreres af sociale konstruktioner og fordomme, minder Popper om Laclau \& Mouffe:

there is no such thing as instruction from without the structure, or the passive reception of a flow of information that impresses itself on our sense organs. All observations are theory impregnated. There is no pure, disinterested, theory-free observation (Popper, 1994:8)

Og andetsteds hedder det ligefrem: "theories are like sense organs" and "our sense organs are like theories" (Popper, 1994:8). Den store forskel mellem Popper og Laclau \& Mouffe er dog, at Popper eksplicit fastholder, at vores konstruktioner eller teorier om virkeligheden hele tiden må udsættes for realitetstjek gennem kritisk diskussion, hvilket indebærer, at de også må udvikle sig og præciseres for at blive ved med at udgøre troværdige bud på en forståelse af det virkelige. På den måde bevæger vidensproduktionen sig henimod den mere sofistikerede teori, men ikke henimod den endegyldige eller fordomsfri sandhed om realiteten (som er principielt uopnåelig). Vejen mod den bedre viden om virkeligheden 


\section{Carsten Stage}

(eller eksistensniveauet) går som tidligere nævnt ikke over absolut objektivitet eller subjektiv distancering under vidensproduktionen, men i stedet over viljen til kritisk diskussion af teoriers konsekvenser (Popper, 1994:22). "Objectivity rests on criticism, on critical discussion, and on the critical examination of experiments", som det hedder (Popper, 1994:8). Dette er en vigtig nuancering, som må medregnes for at undgå den førnævnte "ontological muteness of constructionism" (Nightingale and Cromby 2002:710).

\subsection{Sprog og identitet}

Hvis man følger den meget udfoldede diskursanalytiske teoridannelse om forholdet mellem sprog og identitet, betragtes sproglige ytringer generelt som producenter af 'subjektpositioner' - eller forestillinger om, hvilke identitetskategorier, der skal knyttes til hvilke betydninger (Frello 2003, Laclau and Mouffe 2001, Foucault 2005, Fairclough 1992, Billig 2006, Wodak et al. 2005, Howarth 2005, Jørgensen and Phillips 2006). Disse indgår som identifikationsresurser både i individers selvfortællinger og i deres forståelse af andre. ${ }^{7}$ Michel Foucault, som er diskursanalysens førstemand, kobler allerede i Vidensarkaologien (1969) diskursbegrebet til et identitetsperspektiv, fordi diskursen betragtes som subjektivitetsproducerende, i den forstand at den skaber en række subjektpositioner, som bliver tilgængelige (eller uomgængelige) for det enkelte individ i og med diskursens realisering (Foucault 2005:103). En samtale mellem en læge og en patient struktureres som eksempel af en medicinsk diskurs, som fordrer, at de talende indtager særlige positioner og følger særlige regler ( $\mathrm{fx}$ begynder patienten sjældent at spørge til lægens helbred). En diskursanalyse indebærer med Foucault derfor også en karakteristik af de former for subjektivitet, som diskursen muliggør/ tillader (jf. modalitetsbeskrivelsen). Dette perspektiv på identitetsdannelsesprocesser medfører en 'decentrering' af subjektet, fordi det bliver til og udvikles inden for en kontekst struktureret af diskurser, hierarkier og normalitetsforestillinger, som det ikke kontrollerer.

Hvordan subjektposition og subjektivitet skal tænkes i relation til hinanden er dog et stridspunkt. Hvor meget er den enkelte fx selv herre over, hvilke identitetskategorier det kobles til (jf. agency-problematikken), og i hvor høj grad findes der subjektivitet uafhængigt eller før de subjektpositioner, som man bruger til at forstå og fortælle sig selv og andre med? Flere teoretikere, der forsøger at omgå den mangel på individuel handlekraft, som Foucault ofte beskyldes for at installere, opererer med et implicit skel mellem subjektpositioner som sprogligt 
genererede identitetsforestillinger og subjektivitet som den specifikke individualitet, der udvikler sig ved at relatere sig til subjektpositionerne på særlige måde.

Som eksempel fremhæver Stuart Hall på linje med eksempelvis Richard Jenkins begrebet 'identifikation' som en mulig vej til at gentænke identitetsdannelsen ved hjælp af mere dynamiske termer end det statiske begreb 'identitet' (Jenkins 2006:5). Identifikationsbegrebet har den styrke, at det som udgangspunkt udtrykker en handling/proces, samtidig med at det åbner for, at subjektet kan bidrage til sin egen selvdannelse ved at bekræfte, udvikle eller negere identifikationsmuligheder. Identiteten eksisterer som sådan ikke frigjort fra identifikationens aktivitet: "If there is need for identification, it is because there is no identity, in the first place", som Laclau har skrevet det (Laclau 1996:56). Hall skelner i den forbindelse mellem en naturalistisk og en diskursiv forståelse af identifikationsbegrebet:

In common sense language, identification is constructed on the back of a recognition of some common origin or shared characteristics with another person or group, or with an ideal, and with the natural closure of solidarity and allegiance established on this foundation. In contrast with the 'naturalism' of this definition, the discursive approach sees identification as a construction, a process never completed - always 'in process'. [...] Identification is, then, a process of articulation, a suturing, an over-determination not a subsumption. There is always 'too much' or 'too little' - an over-determination or a lack, but never a proper fit, a totality. Like all signifying practices, it is subject to the 'play', of differance. It obeys the logic of more-than-one. And since as a process it operates across difference, it entails discursive work, the binding and marking of symbolic boundaries, the production of 'frontier-effects' (Hall 2002:2-3)

Grundtanken hos Hall er altså, at identitet dannes gennem et subjekts aldrig fuldendte identifikation med og 'sammensyning' af sociale subjektpositioner af eksempelvis kønslig, seksuel, religiøs og kulturel karakter (Hall 2002:5). Disse positioner distribueres som mulige identifikationsmuligheder gennem sproglige praksisser. Eller med Halls præcise ord: "Identities are thus points of temporary attachment to the subject positions which discursive practices construct for us [...]. They are the result of a successful articulation or 'chaining' of the subject into the 
flow of the discourse [...]" (Hall 2002:6). Den individuelle identitet dannes således gennem den kontinuerlige sammenvævning af subjektivitet med subjektpositioner. For at konkretisere denne pointe kan man sige, at intet menneske er i stand til at præsentere sig selv uden at bruge kategorier, som en lang række andre individer også benytter sig af (fx kvinde, ung, smørrebrødsjomfru, Grete og skagbo), men i sin helhed danner disse fælles kategorier en sjælden eller unik identitetskonfiguration (dvs. der findes uden tvivl relativt få yngre, kvindelige smørrebrødsjomfruer i Skagen, der hedder Grete).

Ifølge en af de mest anvendte 'socialkonstruktivistisk' orienterede bøger om identitetsteori - sociologen Richard Jenkins' Social Identity (2005) - findes der i forlængelse af dette ingen rent private, personlige eller asociale identiteter. Det vil sige at subjekter og subjektpositioner ikke kan tænkes adskilt af hinanden, idet vi altid bliver til dem, vi er, i selskab med andre. Dette skyldes ifølge Jenkins, at individet ankommer til verden som et udefra kategoriseret individ i den forstand, at det frem til 5-6 års alderen hele tiden får at vide, hvor det hører til i en allerede etableret social skematik (fx hvilket køn, hvilken nationalitet (om nogen), hvilken religion (om nogen) det tilhører). Identiteten som eksempelvis 'kristen' er ikke noget nogen fødes med og er fra fødslen, det er noget man muligvis bliver ved $\mathrm{fx}$ at fødes ind $\mathrm{i}$ en familie med en stærk kristen selvforståelse. Dette betyder strengt taget også, at begrebet 'identitet' er misvisende, fordi det er aprocessuelt. Ifølge Jenkins burde man i stedet tale om, at individer konstant er i gang med at identificere sig selv og andre gennem såvel sproglige ytringer som andre sociale praksisser (fx handlinger, påklædning).

Ifølge Jenkins udfordres denne 'fortalthed' i den postinfantile fase, fordi det enkelte individ her i stigende grad selv begynder at vælge at forme sociale identitetskategorier. Fx kan et individ forkaste den kristne identitet, som det er blevet opdraget til at tage på sig, og vælge at være ateist i stedet. Dette betyder dog ikke, at individet går fra at blive fortalt til at blive fortællende, men snarere at der opstår en dialektik mellem den personlige konstruktion af et selvbillede/en selvforståelse og en ekstern respons på denne selvfremstilling, som eventuelt kan føre til at førstnævnte fastholdes eller revurderes (fx ved at man klæder sig på en lidt anden måde for rent faktisk at blive anerkendt som ateist). "Individual identification emerges within the ongoing relationship between self-image and public image", som Jenkins siger det (Jenkins 2006:71). 


\section{Socialkonstruktivisme, sprog og identitet}

Judith Butler udfolder en lignede pointe i sine identitetsteoretiske værker. Etablerede identitetsdiskurser ( $\mathrm{fx}$ angående maskulinitet og femininitet) muliggør således en række interpellationer, som allerede fra fødselstidspunktet integrerer det enkelte subjekt i en diskursiv systematik, samtidig med at subjektet i og med denne indtræden i 'det genkendelige' gives en mulighed for aktivt at bearbejde de sociale diskurser (Butler 2006:196). På den måde tænker Butler overordnet individer som en art 'effektproducerende effekter' af diskursive processer: "Where there is an "I" who utters or speaks and thereby produces an effect in discourse, there is first a discourse which precedes and enables that "I" and forms in language the constrained trajectory of its will" (Butler 1993:225). I Butlers optik er diskurserne dermed både rammen for det tænkelige/handlingen og tænkningens/handlingens mulighed. Handlingen er således altid spundet ind i et system af magtrelationer, som dog ifølge Butler ikke skal betragtes som handlingens modsætning, men som dens eksistensbetingelse (Butler 2006:168-169). Subjektet er altid et objekt for magt, idet dets hele eksistens er indrammet af sociale forudsætninger, som det ikke selv er herre over, men det er også en udøver af magt, fordi det vinder muligheden for agency ved at deltage i bekræftelsen, udviklingen (og udvidelsen) af de diskursive begrænsninger (eller med Popper "frameworks" (Popper 1994)). Subjektets afhængighed af den performative selvbekræftelse bliver således udgangspunktet for en mulig subversion:

Indeed, I would add, a subject only remains a subject through a reiteration or rearticulation of itself as a subject, and this dependency of the subject on repetition for coherence may constitute that subject's incoherence, its incomplete character. This repetition or, better, iterability, thus becomes the non-place of subversion, the possibility of a re-embodying of the subjectivating norm that can redirect its normativity. (Butler 1997b:99)

Butler understreger i den forbindelse ikke-identifikation som en strategi, der kan bruges til at gøre op med dominerende og ekskluderende identitetsdiskurser og udfordre udbredte forståelser af, hvem der kan være og gøre hvad. Ved ikke at identificere sig som forventet skaber man en subversiv handling. Butler nævner som konkret eksempel den sorte kvinde Rosa Parks, der i 1955 trodsede de sociale regler i de amerikanske sydstater ved ikke at ville give sin plads i bussen til en hvid borger, 
da buschafføren bad hende om det. På den måde modsatte Parks sig den racistiske diskurs' interpellation af hende som socialt mindreværdig gennem en subversiv ikke-identifikation med den subjektposition, hun blev tilbudt (Butler 1997a:147). Hun konstruerede med andre ord en ny subjektposition, hvor dette at være sort ikke var lig med social underlegenhed i forhold til de hvide.

Denne teoretiske rammesætning vil jeg sætte i spil i forhold til EMs sygdomsblog. som er interessant i forhold til en konstruktivistisk identitetsanalyse af flere årsager. Fx fordi bloggen kan betragtes som en lang sproglig identitetsrefleksion, idet EM både bruger bloggen til at komme overens med sygdommen som et kropsligt vilkår, til at fastholde andre identiteter end netop identiteten som cystisk fibrosepatient, til at danne nye fællesskaber med andre patienter og sympatisører, og sidst, men ikke mindst, til at forsøge at forandre EMs sociale og samfundsmæssige position samt samfundets syn på eller interesse for cystisk fibrose. EM er således et godt eksempel på, at sproget kan være med til at nyskabe subjektpositioner, genforhandle relationer mellem subjektivitet og subjektposition - men også på, at sproget er begrænset af kropslige vilkår (den proces, EMs krop undergår) (Plummer 1995, Nightingale and Cromby 2002).

\section{65 Red Roses}

Det interessante ved EM i en diskussion af forholdet mellem sprog, identitet og samfund er, at hun ikke kan gøre meget andet end at skrive pga. af sin sygdom, men at denne kommunikation både forandrer 1) hendes egen sociale identitet og 2) den sociale virkelighed, hun interagerer med og i. Hun etablerer således gennem sine sociale interventioner en $\emptyset$ get social bevidsthed om sygdommen cystisk fibrose i det canadiske samfund og om nødvendigheden af organdonation, dvs. hun forandrer den sociale virkelighed ved at præge den gennem sin kommunikation på bloggen og i andre medier. Med Laclau og Mouffe ændrer hun i og for sig både sygdommens og sin egen syge krops sociale væren eller status ved at kommunikere og påvirke samfundets diskurser. Ved at blogge vender hun desuden paradoksalt sin sygdom og svaghed til en styrke, fordi hendes historie kan anvendes til at gribe og forandre modtagerens antagelser. 


\section{Socialkonstruktivisme, sprog og identitet}

\subsection{Virkeligheds- og identitetsforandrende kommunikation}

Bloggen begynder som en lille og afsondret platform i 2006, som kun meget få følger, mens EMs afskedsvideo i 2010 modtager næsten 2500 kommentarer fra folk over hele verden. ${ }^{8}$ Bloggens kommunikation har desuden haft en række tydelige virkelighedeffekter, og har vakt en del politisk interesse. Joyce Murray, medlem af det canadiske House of Commons, hædrede således EM i parlamentet for hendes indsats for at skabe opmærksomhed omkring cystisk fibrose og organdonation. Dette var første gang i seks år, at sygdommen blev nævnt i det canadiske parlament, hvilket vidner om EMs evne til at sætte en bredere dagsorden. ${ }^{9}$ Murray berørte også EMs store mobiliseringskraft: "After her awardwinning documentary 65 Red Roses was broadcast, organ donations increased around the world and tripled in Canada alone". ${ }^{10}$

EM førte også denne kamp for øget fokus på organdonation gennem en række kampagner og tiltag, som stadig kører med relativ tydelig effekt. Eller som det hedder på en af de seneste indlæg på bloggen: "BC TRANSPLANT reports that the 'LIVE LIFE, PASS IT ON' campaign has had significant results, with a demonstrable increase in the rate of organ donor sign up". ${ }^{11}$ EMs blog fremviser sidst, men ikke mindst, eksempler på individuelle responser på hendes kommunikation: "Great video I watched it early this year and it gave me hope I have CF myself and I was lucky to recieve new lungs on 17/3/08 I feel great, I had to come back and watch this again. Keep up the good work your video helped me sign up for my transplant! God bless xxxx". ${ }^{12}$

EMs evne til at præge sine omgivelser hænger tæt sammen med hendes evne til at mobilisere både nationale og internationale medier, hvilket - som et kuriosum - bl.a. førte til, at EM blev en kendt mediepersonlighed i Polen. EMs sociale identitet forandres dermed fra at være en ukendt skoleelev til at være en kendt 'medieaktivist' - særligt i Canada, men også i andre dele af verden. Men hvorfor denne sociale effekt og voldsomme medieinteresse? Den primære grund er, at EM er uhørt åben omkring sin tilstand og lidelser. Med andre ord synes EM ikke at fastholde mange elementer i sit liv som strengt private ligesom hun går meget langt for at kommunikere alvoren af sine lidelser til bloggens brugere. EMs kommunikation er stærkt affektivt ladet, hvilket ikke mindst er tydeligt i den meget sete afskedsvideo fra d. 11.2.2010, hvor EM med sin tydeligt berørte famile (søsteren, moderen og faderen) ved sin side i sygesengen forklarer, at hun har fået dårligt nyt fra lægerne: 
"My life is ending and my family is here, my friends are here and we are sharing good memories and laughing... all the special times we have had together, which is really great (...) So this is the end of my life, but it is not the end of my love. It is pretty cool. (...) If you have any messages for me, send them now before I go (...)". ${ }^{13}$ Denne form for ekstremt åbenhjertig dokumentation af sygdommen og dens konsekvenser gør EM til en socialt vedkommende aktør, som det er svært ikke at lytte og forholde sig til.

To dage før sin død lægger EM følgende sidste tekst ud, som dermed reelt kommer til at fungere som de egentlige afskedsord:

i'm at that point now / i'm done with the poetics / asking for help / my sister is helping me write / actually helping me write / the medications have been piling up / they are taking their toll / i am supersaturated with medications / i've been medically missing in action for two days / the docs started taking me off some of them to see how i would manage / and i am not managing / not managing at all / i'm drowning in the medications / i can't breathe / every hour / once an hour / i can't breathe / something has to change ${ }^{14}$

For mange vil det sikkert virke voldsomt eller endda forkert at mediere sine sidste dage på denne måde, men EM når undervejs til en positiv erkendelse af, at hun kan bruge sin tilstand og sproglige kompetencer til at påvirke andre individer gennem bloggen:

i've lost my freedom as a 25 year old. i've lost my ability to work at all. i am no longer independent. it seems all $\mathrm{i}$ have to offer is my voice. my words. my ideas. who knew that this could be enough? that my goal of helping kids who need it was being met without my knowing? that somewhere out there in a world i can't even imagine someone might hear what $\mathrm{i}$ have to say? and take it to heart? ${ }^{15}$

Den meget afprivatiserede kommunikation handler således om at skabe effekter på virkeligheden gennem læsernes affektive respons på bloggen og emotionelle investering $i$ hendes situation. På den måde transformerer EM reelt sygdommen til et kommunikativt våben.

For at forstå EMs evne til at fange sine læsere og den bredere kontekst må hendes alder og hendes fysiske fremtræden uden tvivl også tages i betragtning (Stage 2013). Det er således både et meget ungt 
og smukt menneske, der udstiller sin dødsproces, hvilket motiverer en oplevelse af et stort tab af potentielt liv. Bloggens evne til at gribe modtageren ville således med stor sandsynlighed være mindre, hvis bloggeren var et ældre menneske, der havde levet et helt liv. Derudover har bloggen som helhed et meget gribende forløb, fordi man følger et alvorligt sygt menneske, der gennemgår et dramatisk forløb over fire år. Først er hun alvorligt syg, så opereres hun og bliver næsten rask for til sidst at blive meget syg igen. Grænsen mellem success og tragik er således hårfin, hvilket skaber et stort identifikations- og mobiliseringspotentiale.

\subsection{Selvbilleder og ikke-identifikation}

EMs blog handler dog ikke alene om at øge samfundets fokus på cystisk fibrose gennem en ultimativ ærlighed angående egne lidelser, men også om EMs konstruktion og genforhanling af sin egen identitet (Kimby 2007, Pitts 2004, Orgad 2005). EM bruger således ikke kun bloggen til at blive en effektfuld social aktør, men også til 1) at forstå og komme overens med sin identitet som syg, 2) at fastholde, at hun er 'mere end syg', og 3) at hun er syg på en måde, der ikke stemmer overens med den sociale forventning om, hvad en dødeligt syg person er og kan gøre. Med andre ord er det altså et flerenstrenget og paradoksalt identititetsarbejde, som udfoldes på 65 Red Roses.

En del indlæg på bloggen tematiserer, hvad det fysisk vil sige at have cystisk fibrose, og hvordan den påvirker EMs liv og sociale relationer. På den måde kommunikerer EM for at forstå sin egen tilstand og den sygdomsidentitet, som er et vilkår for hende. Andre indlæg synes dog mere at betone, at EM er et komplekst subjekt, der er andet end syg. Det gælder ikke mindst de mange dokumentationer af EMs kreative tiltag, bl.a. kort, der skal rejse penge til cystisk fibrose, malerier, ansigtsudsmykning (ansigtsmalerier, make-up, nye frisurer og hårfarver) samt æstetiserende gengivelser af hendes medicin og omgivelser. Derudover lægger EM en del selvfremstillende billeder ud på bloggen, hvor hun bl.a. poserer som model (fx i sygesengen). ${ }^{16} \mathrm{Alt}$ dette har til formål at vise, at EM ikke bare er syg, men også skabende, smuk og foranderlig.

Som nævnt redefinerer hun dog også selve identiteten som 'terminalt syg', dvs. de gængse forventninger om, at man er svag og passiv, hvis man lider af en dødelig sygdom. Et tydeligt eksempel er, at EM benævner sig selv og sine fæller som 'CF warriors"17, dvs. "cystisk fibrose-krigere', hvilket gennem en oxymoron-lignende konstruktion 


\section{Carsten Stage}

skaber en ny subjektposition, hvor der muligt både at lide af en invaliderende sygdom og være en kriger. På den måde genforhandler hun subjektpositionen 'terminalt syg' og skaber dermed, hvad Butler ville kalde en form for ikke-identifikation, fordi hun nægter at ækvivalere sin status som syg med svaghed, passivitet og social udsondring. Tværtimod bruger hun som vist sygdomsdokumentationen til at blive socialt magtfuld, aktivt og socialt central.

Hvis man kigger på Murrays førnævnte hyldest til EM i det canadiske parlament, er det tydeligt, at denne selvfremstilling og genforhandling accepteres. Murray overtager således EMs retorik, når hun siger: "Over the years her parents Janet and Bill supported Eva's determination to live life fully despite her disease. Queen's Jubilee medal winner, Miss New Westminster Ambassador, university grad, activist, warrior, to say Eva inspired us is an understatement". ${ }^{18}$ Med Jenkins opstår der dermed en identitetsskabende overenstemmelse mellem EMs selvbillede og det offentlige billede af hende, og med Hall en identitetsskabende kobling mellem et subjekt (EM) og en socialt virksom subjektposition ('CF warrior').

Undervejs i processen er det dog også tydeligt, at EMs selvbillede faktisk transformeres. I tiden efter lungetransplantationen, hvor alt går planmæssigt, er det som om EM i glimt begynder at lægge sygdomsidentiteten bag sig. Eller med Jenkins: Hun stiller et nyt selvbillede til skue for offentligheden. I februar 2008 hedder det således i et indlæg om en tidligere produceret video, der viser hendes besvær med at trække vejret: "It's not as scary when you know the outcome. I am well again. And for those of you who are living this right now....it does get better. There is hope. My thoughts are with you. I won't forget what it's like to be you". ${ }^{19}$ Selvom EM insisterer på, at hun ikke vil glemme sin sygdomsidentitet, udstiller indlægget dog en form for identitetsmæssig distancering, der viser, at EM i stadig mindre grad identificerer sig som alvorligt syg. "I won't forget what it's like to be you" markerer således en besværgelse af et identitetsbånd, der ikke desto mindre hører fortiden til. "Jeg var som jer, men ikke længere" synes pointen at være.

\subsection{Eksistens vs. væren}

En dødelig genetisk sygdom har selvsagt en eksistens uafhængigt af, om der tales om den eller ej. Uopdaget og ikke-italesat eksisterer den stadig i en krop. Men idet den opdages og virker ind på et individs liv, selvforståelse og sociale relationer bliver sygdommen spundet ind i sociale forestillinger og diskurser, som betyder, at den trods sin 


\section{Socialkonstruktivisme, sprog og identitet}

ufravigelige eksistens også bliver et socialt fortolket fænomen. Men for en god ordens skyld: Jeg mener naturligvis ikke, at individer i verden får cystisk fibrose ved at tale om den, men at deres og andres tale om sygdommen er med til at påvirke, hvordan konteksten forstår, forholder sig til og handler (eller ikke) i forhold til sygdommen. Hvis et individ som et tænkt eksempel i stedet havde italesat cystisk fibrose som en guddommelig straf og haft held med at sprede denne antagelse, ville sygdommens sociale status forandres sammenlignet med EMs artikulation, selvom dens fysiske eksistens var uforandret. Med Laclau og Mouffe in mente er det derfor vigtigt for et fænomens sociale væren, hvilke diskurser, der cirkulerer i en given kontekst. Ikke fordi disse diskurser skaber det, de handler om, men fordi de strukturerer den sociale adgang til fænomenet og dermed også påvirker, hvilke fortolkninger og handlinger der fremstår som plausible eller det modsatte i relation til fænomenet.

Med konstruktivistiske termer går hele EMs projekt i og for sig ud på at ændre cystisk fibroses sociale væren ved at øge offentlighedens kendskab til sygdommen. Eller rettere: Hun prøver at give en næsten glemt sygdom en social væren, som den ellers kun har haft i begrænset omfang. EMs sociale aktivering anvender hendes egen gribende livsfortælling som katalysator og etablerer desuden en handlingsanvisning: at alle bør melde sig som organdonorer. Og som vist har hendes multimodale artikulationer netop stort held med at konstruere cystisk fibrose som en sygdom, der burde have offentlighedens interesse, og som flere mennesker skal handle aktivt for at afhjælpe.

EM er selv meget fokuseret på, at hendes sproglige kommunikation på bloggen også 'konstruerer' hendes egen sociale eksistens ved at producere viden om hende og dermed påvirke den måde folk forholder sig til hende på. Da hun igen får problemer med at trække vejret, fordi hendes krop begynder at afstøde de transplanterede lunger, skriver hun således: "i haven't written in here for so long because / i'm scared it will make it real / i'm scared of who can see this / i never know where to start / i'm too busy / i'm never alone". ${ }^{20}$ Med Jenkins kan man sige, at EMs selvforståelse har forandret sig, men at hun endnu ikke har ladet denne selvforståelse influere på det sociale billede af hende som en person, der har overlevet et dramatisk sygdomsforløb. Hun er således bevidst om, at hun muligvis er syg igen (på eksistensniveauet), men at hendes sociale identitet først forandres, når kontekstens viden om hende også ændres gennem et sprogligt bidrag. 


\section{Carsten Stage}

\subsection{Hvilken konstruktivisme?}

Udgangspunktet for denne artikel var at teste relevansen af en konstruktivistisk identitetsforståelse i mødet med en case, der er tydeligt influeret af førsproglige forhold (en genetisk sygdom). I lyset af analysen er det derfor relevant at diskutere, hvilke af de fire konstruktivismetyper som Collin opstiller (jf. teoriafsnittet), der er meningsfulde i forhold en fyldestgørende forståelse af casen.

Der er intet i casen som underst $\varnothing t t e r$ den mest kontroversielle konstruktivismevariant, der argumenterer for, at den fysiske virkelighed er en konstruktion af vores videnskabelige viden om den. Det virker således absurd, at det skulle være en særlig vidensproduktion, der i sig selv 'sætter' EMs sygdom som et ontologisk fænomen. Det andet grundudsagn - at vores videnskabelige viden om den fysiske virkelighed er en konstruktion - ligger uden for, hvad empirien beskæftiger sig med. Det er dog et faktum, at den naturvidenskabelige viden om cystisk fibrose har forandret sig over tid, og at den kan ændre sig i fremtiden, hvilket delvist underst $\varnothing t t e r$ dette udsagn ved at pointere, at der altid er element af fortolkning i enhver form for vidensproduktion (Popper 1994). Den umiddelbart mest givende konstruktivismeforståelse i forhold til casen er dog uden tvivl relateret til det tredje udsagn - den sociale virkelighed er en konstruktion af vores videnskabelige, dagligdags eller abstrakte viden om den - fordi den netop kan hjælpe med at understrege, at bloggen er med til at ændre EMs egen plads i den sociale virkelighed, men også hvilke fænomener denne socialitet forholder sig til som væsentlige og presserende.

Som vist medfører EMs kommunikation, at hun bevæger sig fra en status som en ukendt borger og patient til at være en socialt anerkendt patient-aktivist og mediepersonlighed, der bl.a. genkendes som en 'cf warrior'. Derudover lykkedes det hende at skabe substantial opmærksomhed omkring en ellers ofte glemt sygdom, og hun forandrer dermed sygdommens sociale værensform (fra mindre vigtig til vigtig) og herunder en stor gruppe menneskers handlinger i forhold til fænomenet (jf. alle de mennesker, der melder sig som organdonorer pga. hendes kommunikation). På den måde er hendes sproglige kommunikation ikke strengt refererende i forhold til det sociale, men også med til at forme, hvad der skal toelle som hvad inden for socialitetens rammer. På den baggrund er det fjerde konstruktivistiske grundudsagn - vores viden om den sociale virkelighed er en konstruktion - selvsagt også relevant, men det er som tidligere nævnt et så alment accepteret synspunkt, at det ikke i sig selv giver noget til analysen. 


\section{Socialkonstruktivisme, sprog og identitet}

Der er dog et forhold, der mudrer denne ellers klare præference for en konstruktivisme, der argumenterer for, at sproget alene er med til at konstruere den sociale virkelighed. For hvordan kan vi vide, at EMs kommunikation ikke også er med til at forme hendes fysiske tilstand? Dette kan vi ret beset ikke bevise eller modbevise, men det virker langt fra usandsynligt, at bloggen enten har hjulpet hende gennem svære tider med positive fysiske resultater til følge, eller at den medieopmærksomhed den skabte har stresset hende med negative fysiske resultater tilfølge. Med andre ord er skellet mellem den sociale krop (hvis væren/ identitet kan forandres gennem sproglige processer) og den fysiske krop (med en førsocial eksistens) temmelig svært at etablere entydigt. For hvor hører den sociale virkelighed helt præcist op, og hvor begynder den fysiske virkelighed i forhold til EMs forløb? Jeg er som nævnt enig $\mathrm{i}$, at der findes en fysisk eksistens, der yder modstand eller understøtter specifikke betydningsproduktioner i forhold til casen (dvs. den genetisk bestemte sygdom), men vil dog fastholde, at det reelt er svært at afgøre, hvor meget og hvordan det sproglige, sociale og fysiske er vævet sammen. EMs sociale og fysiske eksistens er ikke det samme, men kan heller ikke adskilles entydigt.

Dette problem peger på noget centralt og problematisk i hele konstruktivisme/realisme-diskussionen, nemlig at den ofte kommer til at dreje sig om, hvorvidt man primært mener, at virkeligheden determinerer vores videns- og sprogproduktion, eller man primært mener vores videns- og sprogproduktion præger virkeligheden. Dette er et problem, fordi konstruktivismen dermed etableres som en position, der grundlæggende betvivler eksistensen af noget uden for sproget, mens den for mig at se primært er interessant, fordi den spørger åbent og undersøgende til relationen mellem det sproglige, sociale og fysiske. På den baggrund bliver realisme/konstruktivisme-modsætningen til en blindgyde, fordi det fysiske og det sociale, det materielle og det sproglige, det naturlige og det menneskeskabte reelt hele tiden sammenvæves og virker tilbage på hinanden. Eller med Burrs ord:

(...) material conditions generate, but do not determine, social constructions which in their turn ground actions and decisions which then have real consequences. So that although material conditions provide the ground in which discourses may take root, once constructed those discourses channel action which itself then transforms the nature of the real world (Burr 2003:190) 


\section{Carsten Stage}

Dette standpunkt indebærer desuden, at sproget hverken reduceres til blot og bar reference eller blot og bar konstruktion af verden eller identiteter, men netop hele tiden betragtes som en medierende faktor, der i visse situationer refererer til og i andre præger virkeligheden. Nightingale og Cromby plæderer netop for en konstruktivismeforståelse, der undgår såvel en naiv skepticistisk/idealistisk tro på sprogets evne til at sætte det virkelige som en naiv realistisk forestilling om, at sproget ikke er med til at forme individers forståelse af verden og dermed deres handlinger i den (Nightingale and Cromby 2002). Dette fører til en sprogforståelse hvor:

(...) language is never a perfect mirror of materiality. But this need not entail that we consider it autonomous, transcendent, freefloating and wholly self-referencing; instead, language performs flawed, incomplete reference. (...) The play of linguistic meaning and signification is shaped and constrained by embodiment, materiality, socio-cultural institutions, interpersonal practices and their historical trajectories (all of these structured by, and reproducing structures of, power) such that language does not independently and thoroughly constitute our world. But within such constraints, language, in its objective materiality, discursively co-constitutes the realities we experience (Nightingale and Cromby 2002:705706)

Med EM som eksempel er det altså både forkert at påstå, at hendes syge krop er sprogligt konstituteret, og at den er komplet førsproglig, fordi såvel hendes egen som andres kommunikation også kan være med til at påvirke både hendes sociale status/position og hendes fysiske tilstand. Konstruktivismen analyserer inden for denne forståelsesramme i gråzonen mellem det fysiske og det diskursivt-sociale og forsøger at forstå relationerne mellem de sproglige antagelser, der etableres i en kontekst, det sociale liv, der leves i konteksten, og konteksten som fysisk virkelighed og vilkår.

I forhold til analysen af EMs blog og sygdomsforløb medfører denne spørgen til forholdet mellem det sproglige, sociale og fysiske, at man på én gang kan have blik for 1) at det virkelige ikke er rent socialt konstitueret, fordi sygdommen selvsagt udgør et ikke-sprogligt konstitueret vilkår for EMs liv, 2) at den sociale forståelse af både den sygdomsramte og sygdommen selv kan forandres gennem sproglige artikulationer, der genforhandler deres plads i socialiteten, og 3) at skel- 


\section{Socialkonstruktivisme, sprog og identitet}

let mellem sygdommen som fysisk eksistens og socialt fænomen kan være svær at drage tydeligt, fordi de sociale processer kan virke tilbage på den fysiske eksistens på forskellige måder (fx ved at svække/styrke EMs tilstand).

\section{Konklusion}

I denne artikel har jeg på baggrund af en diskussion af konstruktivismeog identitetsbegrebet analyseret en sproglig kommunikationsplatform med fokus på dens identitetsforhandlinger. Jeg har vist, at EM formår at ændre sin sociale identitet gennem bloggen, at hun anvender den til både at forstå og overskride identiteten som terminalt syg, og at hun formår at præge bl.a. den canadiske samfundskontekst ved at $\emptyset$ ge mediers og politikeres fokus på cystisk fibrose. Disse pointer har jeg anvendt til at diskutere forskellige konstruktivismeargumenters relevans i forhold til casen, og jeg har argumenteret for, at en kontruktivisme, der fokuserer på, hvordan sprog og vidensproduktion kan påvirke en social virkelighed, men ikke nødvendigvis fænomeners fysiske eksistens, er den umiddelbart mest anvendelige. Denne præference forstyrres dog af det faktum, at det reelt kan være svært at adskille fx en krops eller en sygdoms sociale status og fysiske eksistens fra hinanden, fordi det sociale og sproget også motiverer handlinger (fx organdonation) med fysiske konsekvenser ( $\mathrm{fx}$ et reddet menneskeliv).

Analysen tydeligg ør dermed ikke mindst, at forestillingen om en klar og logisk modsætning mellem teorier, der primært betragter virkelighed/identitet som en effekt af sproglige italesættelser, og teorier, der primært funderer virkelighed/identitet i førsproglige vilkår ( $\mathrm{fx}$ hormoner og gener), ikke bidrager opklarende til at forstå bloggens identitetskommunikation. For når det kommer til at forstå en dødelig sygdoms identitetsmæssige konsekvenser, er der tydeligvis en del identitetsarbejde på spil, som ikke er sprogligt funderet, ligesom den konkrete sociale betydning af disse identitetsvilkår, samt muligvis også det konkrete sygdomsforl $\varnothing b$, hele tiden bearbejdes og præges gennem sproglige artikulationer. Casen viser dermed, at det mest konstruktive konstruktivistiske udgangspunkt er at anerkende en fysisk eksistens, der ikke (altid) sættes af sproget, samtidig med at man holder et vågent analytisk $\varnothing j e$ med, hvordan det sproglige, det sociale og det fysiske alligevel ofte sammenvæves. 


\section{Carsten Stage}

\section{Noter}

1 Bloggens navn refererer - med undtagelse af adjektivet 'red' - til en talefejl, som ofte opstår, når sygdommen skal udtales på engelsk (jf "cystic fibrosis").

2 http://65redroses.livejournal.com/98141.html (set 2.1.2012).

3 http://65redroses.livejournal.com/98141.html (set 2.1.2012).

4 Jeg skelner her ikke mellem 'konstruktivisme' og 'socialkonstruktivisme'.

5 Collins bud på en teoretiker, der repræsenterer dette standpunkt er Bruno Latour.

6 Diskurs defineres af Phillips og Jørgensen som "en bestemt måde at tale om og forstå verden (eller et udsnit af verden) på" (Jørgensen og Phillips, 2006: 9).

7 Dele af dette afsnit om sprog og identitet er hentet fra teoridelen af min afhandling Et andet Danmark. Konstruktionen af national identitet $i$ danske medier under tegningekrisen (2009), som er udgivet i en bearbejdet form under titlen Tegningekrisen - som mediebegivenhed og danskhedskamp (2011).

8 http://65redroses.livejournal.com/2010/02/11/ (set 2.1.2012).

9 http://65redroses.livejournal.com/140407.html (set 2.1.2012).

${ }^{10} \mathrm{http}: / / 65 \mathrm{redroses} .1$ ivejournal.com/140407.html (set 2.1.2012).

${ }^{11} \mathrm{http}: / / 65 \mathrm{redroses}$. livejournal.com/147311.html (set 2.1.2012).

${ }^{12} \mathrm{http}: / / 65 \mathrm{redroses} . l i v e j o u r n a l . c o m / 2008 / 08 / 06 /$ (set 2.1.2012).

${ }^{13} \mathrm{http}: / / 65 \mathrm{redroses}$. livejournal.com/134498.html (set 2.1.2012).

${ }^{14}$ http://65redroses.livejournal.com/139069.html (set 2.1.2012).

${ }^{15} \mathrm{http}: / / 65 \mathrm{redroses}$. livejournal.com/118901.html (set 2.1.2012).

${ }^{16}$ Eksempler på EMs creative udfoldelser: http://65redroses.livejournal.com/34170.html, http://65redroses.livejournal.com/17855.html, http://65redroses.livejournal.com/13548.html, http://65redroses.livejournal.com/23881.html, http://65redroses.livejournal.com/17045.html (set 2.1.2012).

17 http://65redroses.livejournal.com/86550.html (set 2.1.2012).

18 http://65redroses.livejournal.com/140407.html (set 2.1.2012).

19 http://65redroses.livejournal.com/42315.html (set 2.1.2012).

20 http://65redroses.livejournal.com/2009/08/30/ (set 2.1.2012).

\section{Litteratur}

Billig, M. (2006). Banal Nationalism, London: Sage.

Burr, V. (2003). Social Constructionism, New York: Routledge.

Butler, J. (1993). Bodies that matter. On the discursive limits of "sex", New York: Routledge. 
Butler, J. (1997a). Excitable Speech. A Politics of the Performative, New York: Routledge.

Butler, J. (1997b). The Psychic Life of Power, Stanford: Stanford University Press.

Butler, J. (2006). Gender Trouble, New York: Routledge.

Collin, F. (2003). Konstruktivisme, Frederiksberg: Samfundslitteratur.

Fairclough, N. (1992). Discourse and Social Change, Cambridge: Polity.

Foucault, M. (1963). The Birth of the Clinic (Naissance de la Clinique), Oxon: Routledge.

Foucault, M. (2005). Vidensarkceologien, Århus: Philosophia.

Frello, B. (2003). Identiteter på spil. Medierne og krigen i Kosovo, København: Forlaget Politiske Studier.

Hall, S. (2002). Introduction: Who Needs 'Identity'?, I: S. Hall (red.), Questions of Cultural Identity, London: Sage.

Heilferty, C. M. (2011). Ethical considerations in the study of online illness narratives: a qualitative review, Journal of Advanced Nursing 2011:945953.

Howarth, D. (2005). Diskurs. En introduktion, København: Hans Reitzels Forlag.

Jenkins, R. (2006). Social Identity (2. ed.), London: Routledge.

Jørgensen, M. W. \& L. Phillips (2006). Diskursanalyse som teori og metode, København: Roskilde Universitetsforlag/Samfundslitteratur.

Kimby, C. (2007). At skrive selvet. Brystkraftramte kvinders sygdomsrelaterede internetbrug, København: Københavns Universitet.

Kress, G. \& T. van Leeuwen (2001). Multimodal Discourse. The modes and media of contemporary communication, London: Arnold.

Laclau, E. (1996). Deconstruction, Pragmatism, Hegemony, I: C. Mouffe (red.), Deconstruction and Pragmatism, London: Routledge.

Laclau, E. \& C. Mouffe (1987). Post-Marxism without Apologies, New Left Review (166):79-106.

Laclau, E. \& C. Mouffe (2001). Hegemony and Socialist Strategy. Towards a Radical Democratic Politics (2. ed.), London: Verso.

Nightingale, D. J. \& J. Cromby (2002). Social Constructionism as Ontology, Theory \& Psychology, 12 (5):701-713.

Orgad, S. (2005). The Transformative Potential of Online Communication, Feminist Media Studies, 5 (2):141-161.

Pitts, V. (2004). Illness and Internet Empowerment: Writing and Reading Breast Cancer in Cyberspace, Health, 8 (1):33-59.

Plummer, K. (1995). Telling Sexual Stories, London: Routledge.

Popper, K. R. (1994). The Myth of the Framework: In Defence of Science and Rationality, London: Routledge.

Stage, C. (2013). The Online Crowd: A Contradiction in Terms? On the Potentials of Gustave Le Bon's Crowd Psychology in an Analysis of Affective 


\section{Carsten Stage}

Blogging, Distinktion: Scandinavian Journal of Social Theory, 14 (2):211226.

Stage, C. (2014). Online a-liveness: A 'rhytmanalysis' of three illness blogs made by Rosie Kilburn, Jessica Joy Rees and Eva Markvoort, I: D. R. Christensen \& K. Sandvik (red.), Mediating and Re-Mediating Death, London: Ashgate.

Wodak, R., R. de Cillia, M. Reisigl \& K. Liebhart (2005). The Discursive Construction of National Identity, Edinburgh: Edinburgh University Press.

\section{Netsteder}

65 Red Roses: http://65redroses.livejournal.com/ (set 2.1.2012) 